\title{
Identification and Geovisualization of Landscape Transformation of Surface Mine Areas in the Đurđevik Coal Basin (Bosnia and Herzegovina)
}

\author{
Sabahudin Smajić $\mathrm{A}^{*}$, Merima KovačevićA ${ }^{A}$ Dragoslav Pavić ${ }^{B}, \mathrm{C}$ \\ Received: October 30, 2020 | Revised: December 28, 2020 | Accepted: January 11, 2021 \\ doi: 10.5937/gp25-29151
}

\begin{abstract}
The paper researches the landscape transformation of the surface mines of the Đurđevik coal basin (northeastern Bosnia region), where $35.24 \mathrm{Mt}$ of brown coal were produced in the past 74 years, and $227.40 \mathrm{Mm}^{3}$ of overburden was excavated and disposed of. This type of coal exploitation caused the formation concave and convex of anthropogenic relief forms which ultimately led to significant landscape transformation. These transformations were identified and geovisualized on the basis of field research and comparative GIS analysis of archival maps, satellite images, Digital Elevation Models and plans of this area. As a result of the research, especially comparative GIS analysis of two prepared terrain models of surface mines, the transformation of hypsometry, slope and aspect, hydrographic network, pedological as well as vegetation cover were determined. Obtained geospatial data are geo-visualized in QGIS, and as a result, thematic maps were created to provide insight into the essence of transformations. Therefore, established indicators of landscape transformation can serve as a significant factor in planning the revitalization and land re-cultivation of devastated areas in the Đurđevik coal basin.
\end{abstract}

Keywords: Landscape transformation; GIS analysis; DEM; geo-visualizations; open pit; Đurđevik coal basin

\section{Introduction}

Surface coal mining in the Đurđevik coal basin has a 74-year-long tradition and is the main agent of anthropogenic relief. It started in 1946 at the locality "Kažalj potok" and since then it has been carried out at the following localities: "Živčići", "Potočari", "Višća I", "Brezje", "Bašigovci", "Suhodanj" and others, which are closed. Two surface mines are currently active in the Đurđevik coal basin, deep interventions: "Višća II" and "Potočari", whose annual production amount is about 500 thousand tons of coal and about $4.20 \mathrm{Mm}^{3}$ of overburden.

This type of coal exploitation caused the formation anthropogenic relief forms which ultimately led to significant landscape transformation, especially topological (Wu et al., 2019). The transformation of hypsometry, slope and aspect, hydrographic network, pedological as well as vegetation cover was particularly emphasized. Therefore, the characteristics of

\footnotetext{
A University of Tuzla, Faculty of Natural Sciences and Mathematics, Department of Geography; sabahudin.smajic@untz.ba, merima.kovacevic@untz.ba

B University of Novi Sad, Faculty of Sciences, Department of Geography, Tourism and Hotel Management; Trg Dositeja Obradovića 3, 21000 Novi Sad, Serbia; dragoslav.pavic@dgt.uns.ac.rs

c University of Novi Sad, Faculty of Sciences, Climatology and Hydrology Research Centre

* Corresponding author: Sabahudin Smajić; e-mail: sabahudin.smajic@untz.ba
} 
anthropogenic relief and development tendencies require the research of issues, such as: classification and mapping of shapes, quantitative forecast of transformations, determination of re-cultivation measures, etc. (Dinić, 2007; Smajić et al., 2018).

Identification and geo-visualizations analysis landscape transformation at the spatial and temporal level is possible by comparing the natural and anthropogenic relief on the basis of cartographic material, with the application of GIS technology (Smajić, 2012; Smajić et al., 2018). In the process of landscape modeling of mining areas, the factor significance of 3D modeling and interactive visualization options was also emphasized (Brejcha et al., 2016). Therefore, based on archival topographic maps and the recent ALOS DSM, two DEMs (natural and anthropogenic) of the Đurđevik area were prepared, with whose analysis and comparison, quantified and geo-visualized landscape transformations were identified.

Similar studies analyze the pronounced anthropogenic impact on the natural landscape of mining areas, for example, in the Ruhr District in western Germany (Harnischmacher \& Zepp, 2014; Harnischmacher, 2007), the Kolubara basin in Serbia (Dragićević et al., 2012), the Mehedinți County in Romania (Boengiu et al., 2016), Bełchatów Coal Open Mine in central Poland (Jaskulski \& Nowak, 2019), Patratu region in India (Pandey \& Kumar, 2014) etc. These, as well as numerous other studies, also deal with the topic of design, analysis and comparison of digital terrain models of mining areas. A particularly good example of the identification of landscape topography transformation, based on a comparative analysis of DEMs, is the Polish opencast coal mine "Bełchatów", where topographic changes were found in $75 \%$ of the treated area (Jaskulski \& Nowak, 2019). Topographic transformations in the area of surface coal mining in the Patratu region were also identified relying on stereographic satellite images using the DEMs comparison. Positive relief changes have been recorded in the landfill area (up to $49 \mathrm{~m}$ ), while negative ones represent deep depressions (up to $66 \mathrm{~m}$ ) that become zones of water accumulation (Pandey \& Kumar, 2014). Gupta et al. (2014) point out that DEM is generated by synthetic radar interferometry (InSAR) ideal in identifying and estimating altitude changes in mining areas. In this way documented topographic changes in the Indian Jahra field in the period 19962004 are $\pm 40 \mathrm{~m}$. Thomas et al. (2015), on the example of Kerala (India), point out that the application of different terrain models in topographic area analysis is the result of different input data, emphasizing the importance of SRTM and ASTER DEMs in geomorphometric analysis. By comparing the terrain model, e.g. in the Upper Silesian Coal Basin the maximum subsidence above the underground mine galleries of over $30 \mathrm{~m}$ (Machowski et al., 2016; Dulias, 2016) and in the Ruhr District over $25 \mathrm{~m}$ were determined (Harnischmacher \& Zepp, 2014) etc.

In general, the aim of the research is to identify and geo-visualize the achieved level of landscape transformation, especially morphological-hydrographic, areas of surface mines in the Đurđevik coal basin, using field research, methods of comparative analysis of terrain models, and GIS technology.

\section{Study area}

The Đurdevik coal basin $\left(13 \mathrm{~km}^{2}\right)$ is located in the municipality of Živinice (Tuzla Canton) in northeastern Bosnia, between $44^{\circ} 23^{\prime} 27^{\prime \prime}$ and $44^{\circ} 25^{\prime} 18^{\prime \prime} \mathrm{N}$ and $18^{\circ} 35^{\prime} 33^{\prime \prime}$ and $18^{\circ} 39^{\prime} 48^{\prime \prime}$ E. Geotectonic, the area is located in the Spreča paleodepression, within the Bosnian Inner Dinarides (Drešković \& Mirić, 2017), and geomorphologically belongs to the macroregion "Mountains and hills, valleys and valleys of northern Bosnia" (Lepirica, 2013). Topographically, the basin is located in the triangle between the rivers Gostelja in the east, Oskova in the north and Djedinska mountain in the southwest, while the western and southern borders are approximately represented by the surrounding settlements (Figure 1).

The basin is open to the northeast, extending approximately in the NW-SE direction for about 5.50 $\mathrm{km}$, while the width is $1-2.50 \mathrm{~km}$. The general direction of Lower Miocene coal seam (14-25 m thick), is NW-SE, while dipping to the SW. The seam most often lies over lumpy marly-sandy clays and gravels, while the roof is predominantly made up of a series of Lower and Middle Miocene marls and marly limestones (up to 240-300 m thick). Uppermost Pliocene and Quaternary series have a thickness up to $60 \mathrm{~m}$ (Arsenović et al., 2016). In the Đurđevik coal basin, a coal seam of different depths has been developed. In the northern part of the basin, the coal seam is shallow and is exploited with surface mining ("Potočari", "Višća II", etc.), while the deeper coal reserves in the deposit were exploited in the former open pit "Višća I" in the west, the active open pit "Potočari" (deep interventions) in the north, the former open pits "Živčići", "Brezje" and "Suhodanje" in the east, and the active underground pit "Đurđevik" in the south (Long-term work program of BCM “Đurđevik", 2018).

From the foot of Djedinska mountain, the hilly relief forms have a general decline towards Sprečko polje in the north. Mountain streams (Brestovica, Kažalj potok, Višća, etc.) flew in this direction, which used 


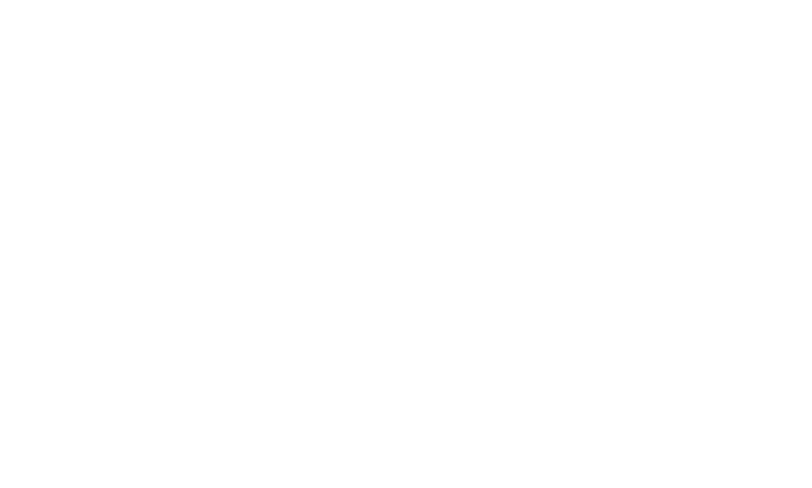

Figure 1. Location of the study area in Bosnia and Herzegovina (a) and the study area (b) to flow into the Oskova river, more northern of the exploitation field. The highest terrains are in the western $(450 \mathrm{~m})$ and southern $(430 \mathrm{~m})$ part of the basin, and the lowest in the Oskova $(230 \mathrm{~m})$ and Gostelja $(233 \mathrm{~m})$ riverbeds. The average height of the Đurdevik exploitation field is $290.99 \mathrm{~m}$, while the height of the area of surface mines was $235-345 \mathrm{~m}$, and now it is $90-360 \mathrm{~m}$.

Exploitation reserves of brown coal in the basin, intended for surface exploitation, amount to $24.29 \mathrm{Mt}$, of which the mine "Potočari" owns $10.65 \mathrm{Mt}$, and "Višća II" $13.64 \mathrm{Mt}$. With the development of Đurđevik's surface mines, six hamlets have completely disappeared, and parts of several rural settlements were relocated (Smajić et al., 2009; Smajić, 2012).

\section{Data and methods}

In order to realize the set goal of the research, it was necessary to conduct field research and develop a DEM of natural and anthropogenic terrain, the comparison which identified and quantified landscape transformations in the area of surface mines. The geospatial data obtained by the applied GIS methodology were geo-visualized after analytical-synthetic processing. The procedure was realized in several research stages.

First, the available cartographic archival material was inspected, which can be used for vectorization of the necessary contents in order to identify and analyze the condition of the Đurđevik area before surface exploitation. Insight into maps of various scales topographic maps at a scale of 1:25,000 (from 1966) are selected, published by the MGI in Belgrade, while the recent state of the Đurđevik area, viewed on the basis of Google Earth Map (satellite image from 2018), ALOS DSM, JAXA (from 2018) and plans of mining surveying, a scale of 1:2,500 (from 2020). The selected AW3D30 DSM is one of the most accurate, medium-resolution altitude datasets (Florinsky et al., 2018), and uses the Advanced Land Observing Satellite (ALOS) based on stereo mapping from Panchromatic Remote-sensing Instrument for Stereo Mapping (PRISM) (Takaku et al., 2018).
After selecting the cartographic basis, four sheets of TM25, the maps were scanned in raster format with a resolution of $400 \mathrm{dpi}$, and then filtering and adjusting the raster for better visual appearance, more precise vectorization, as well as georeferencing maps in the coordinate system of appropriate projection were performed. After georeferencing, using the application Google Earth Pro, the boundaries of the Đurđevik exploitation field, of the working area and the parts of surface mines were vectorized. Using QGIS tools, the vectorization of thematic contents (isohypses, watercourses, soil, vegetation, etc.) was also carried out and then on the basis of this vectorization the analysis of average heights, the presence of hypsometric levels, slopes and aspects, disorganization of the river network, devastation of soil and vegetation in the area of surface exploitation were executed. Vectorization of thematic content from the Google Earth Pro satellite image (anthropogenic lakes, relocated watercourses, canals, etc.) was also carried out.

In particular, two digital elevation models of the Đurđevik area were made, from different periods, which well illustrate the transformations of landscape topography. The prepared models were compared using QGIS tools, and the complex analysis is facilitated by a uniform pixel size (10x10 m).

\section{Results and discussion}

In the past 74 years, surface exploitation in the Đurdevik coal basin, 35.24 Mt of brown coal was produced, which was mainly used for the needs of the thermal power plant "Tuzla", and about 227.40 $\mathrm{Mm}^{3}$ of overburden was excavated and disposed of in landfills. This type of exploitation has generated a significant landscape transformation of the Đurdevik coal basin, especially emphasized in the transformation of morphological, hydrographic, pedogeographic and phytogeographic structure. Areas affected by exploitation are significantly degraded and disturbed by mining operations, so the morphology of the terrain, similar to the neighboring Banovići and Kreka coal basins (Smajić et al., 2018; Smajić \& Hadžimustafić, 
2016; 2017), represents the integration of natural and newly formed anthropogenic relief forms (floors, excavations, open pits, landfills, etc.). Similarly, in the Ruhr District, the consequences of long-term mining activity are still noticeable today, especially in the form of waste heaps differently integrated into the landscape (Harnischmacher, 2007; Harnischmacher \& Zepp, 2014). Specifically, surface exploitation in the Đurđevik coal basin, in addition to several smaller and two larger active open pit mines, formed several external and internal landfills of different dimensions ("Stupnica - T6", "Suhodanj", "Brezje", "Višća", "Potočari", "Kažalj", "Odorovići”, etc.) whose composition is dominated by coal bed sediments, i.e. oligomyocene marls, marly limestones and clays. This tailings material is suitable for biological re-cultivation, especially for plantation cultivation of fruits and vegetables (Salihović \& Operta, 2008). GIS analysis of anthropogenic relief of surface mines showed that open pits cover $33.16 \%$, landfills $44.89 \%$, recultivated areas $10.56 \%$, anthropogenic lakes $4.65 \%$, while other parts account for $6.74 \%$. Significant areas of natural soil ( $861.78 \mathrm{ha})$ in the newly formed anthropogenic relief in the Đurđevik coal basin were devastated, which disrupted natural pedogenetic processes and vegetation. In this way, podzolic-pseudogley terrace $(77.88 \%)$ and slope soils (11.29\%) and brown acid soils on sandstones (5.94\%), brown very shallow and shallow soils on serpentines $(3,04 \%)$, humus-silicate soils on serpentines $(1.03 \%)$, pelosols $(0.77 \%)$ and alluvial-deluvial carbonate-free soils $(0.47$ ha or $0.05 \%)$ were dominantly devastated (The Map of Soil, 1969). Agricultural areas, settlements, forest barren lands and others cover $59.92 \%$ of the basin area, while forest phytocenoses predominantly devastated sessile and hornbeam forests (38.19\%), and pedunculate and hornbeam forests $(1.89 \%)$ (The map of actual forest vegetation, 1980).

Coal exploitation at the "Višća II" mine is planned until 2025, and at the "Potočari" mine until 2037. Until then, it is planned to excavate $91.34 \mathrm{Mm} 3$ of overburden and 9.31 Mt of coal, which requires addition- al expropriation, but also soil devastation. The newly discovered overburden will be partially disposed of in external landfills "Stupnica" and "Višća", and mostly in internal landfills in the pits of active mines, which will form significant areas of technically re-cultivated soil after the end of disposal. From 2026, more intensive activities are planned for the re-cultivation of devastated areas, primarily the "Stupnica" landfill, the "Potočari" internal landfill, etc. (Long-term work program of BCM “Đurđevik", 2018).

\section{Morphological transformation}

The Đurdevik coal basin is located in the foothills of the Konjuh mountain, which is morphologically represented and surrounded by elevations 338448 m high (Mramor, Rudine Redžepovac, Gradina, Bjelanovica, Palež, Nišan and others). The relief of the surface mining area is lower, while the area is entirely located in the foothills, and before exploitation it was characterized by a hilly, slightly undulating relief intersected by tributaries of the Oskova and Gostelja rivers, and generally sloping to the north (Figure 2).

The formation of concave and convex anthropogenic relief forms due to exploitation has significantly transformed the morphology of the Đurdevik area. External landfills have covered the natural terrain and flat surfaces have been formed, while active pits and landfills of surface mines are still subject to spatial changes.

\section{Hypsometric transformation}

Altitude is a significant microclimatic modifier, and most directly affects the direction of biological re-cultivation of devastated areas. Therefore, a hypsometric analysis of the natural and anthropogenic terrain of surface mines was performed, and a 10-meter digital model of the area was used as a basis (Table 1).

The analysis of DEM natural terrain showed that the lowest hypsometric belt (up to $300 \mathrm{~m}$ ) covered $77.58 \%$ of the area, and the highest of its territory had a height of 280-300 m (37.94\%). The belt over $300 \mathrm{~m}$ covered $22.42 \%$ of the area, while more than half of its

Table 1. Categories and spatial dimensions of elevation

\begin{tabular}{|c|c|c|c|c|}
\hline \multicolumn{3}{|c|}{ Natural relief } & \multicolumn{2}{c|}{ Anthropogenic relief } \\
\hline Elevation $(\mathrm{m})$ & Area (ha) & Portion (\%) & Area (ha) & Portion (\%) \\
\hline-100 & - & - & 2.61 & 0.30 \\
\hline $100-200$ & - & - & 63.50 & 7.37 \\
\hline $200-300$ & 668.63 & 77.58 & 419.78 & 48.71 \\
\hline $300-$ & 193.24 & 22.42 & 375.89 & 43.62 \\
\hline Total & 861.87 & 100.00 & 861.78 & 100.00 \\
\hline
\end{tabular}

Source: Data obtained by GIS analysis. Cartographic basis: TM 1:25,000 (1966). Belgrade: MGI; Map Satellite (2018). Google Earth; DSM (2018). Tokyo: JAXA. 
territory had a height of $300-310 \mathrm{~m}$ (52.18\%). The average altitude of the natural terrain was $280.16 \mathrm{~m}$, and the absolute altitude difference was $109.84 \mathrm{~m}$ (Table 1).

The analysis of DEM anthropogenic terrain showed that the lowest belt (up to $100 \mathrm{~m}$ ) covers $0.30 \%$ of the total area, while the $100-200 \mathrm{~m}$ belt covers $7.37 \%$, and the highest territory has a height of 160-200 m (62.18\%). The hypsometric belt of $200-300 \mathrm{~m}$ covers $48.71 \%$ of the area, and the highest territory has a height of $240-300 \mathrm{~m}(83.97 \%)$. The belt over $300 \mathrm{~m}$ covers $43.62 \%$ of the area, while the highest territory has a height of $300-340 \mathrm{~m}$ (96.65\%). The average altitude of the anthropogenic terrain is $280.48 \mathrm{~m}$, while the absolute altitude difference of the terrain is 266.32 $\mathrm{m}$. Similarly, the mean height of both terrains of the Polish mine "Bełchatów" is fairly uniform, while the height difference is more emphasized; before the formation of the anthropogenic relief it was $80 \mathrm{~m}$, and now 482 m (Jaskulski \& Nowak, 2019).

The results of the comparative analysis of DEM show the uniformity of the average height of both terrains. The southern part of the area, where the landfills are the largest, is characterized by the highest levels $(300-360 \mathrm{~m})$, while the northern part, where the open pits are, is significantly lower $(90-315 \mathrm{~m})$. The average height of the "Višća II" pit is $235.56 \mathrm{~m}$, the maximum $286.58 \mathrm{~m}$, while the maximum depth is $180 \mathrm{~m}$. The "Potočari" pit has an average height of $214.07 \mathrm{~m}$, a maximum of $298.21 \mathrm{~m}$, while the greatest depth in the central part is $90 \mathrm{~m}$ (Figure 2).

External landfills, in the southwestern, southern and southeastern part, covered the parts of the valleys of the Kažalj, Višća, Stupnica, Brnjica and other streams. As a result, flattened surfaces of different volume and degree of re-cultivation were formed. The average height of the re-cultivated landfill "Kažalj" is $310.57 \mathrm{~m}$, maximum $329.16 \mathrm{~m}$, and minimum 264.55 $\mathrm{m}$, while the average height of the landfill "Odorovići" is $325.73 \mathrm{~m}$, maximum $333.83 \mathrm{~m}$, and minimum $310.24 \mathrm{~m}$. The average height of the active landfill "Višća" is $310.16 \mathrm{~m}$, maximum $339.72 \mathrm{~m}$, and minimum $259.19 \mathrm{~m}$, while the average height of the active landfill "Stupnica" is $321.78 \mathrm{~m}$, maximum $356.33 \mathrm{~m}$, and minimum $258.57 \mathrm{~m}$.

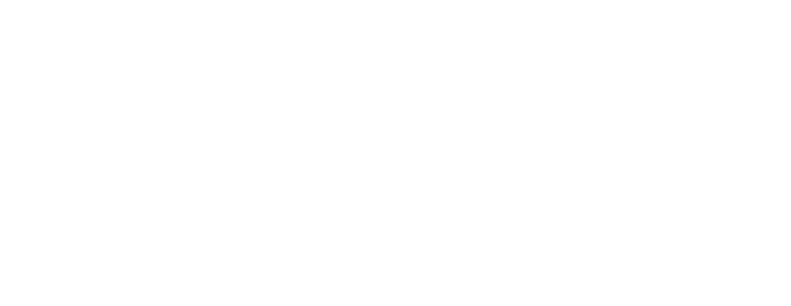

Figure 2. Cross-profile (A-B-C-D-E-F) in a section of hypsometric map of the study area

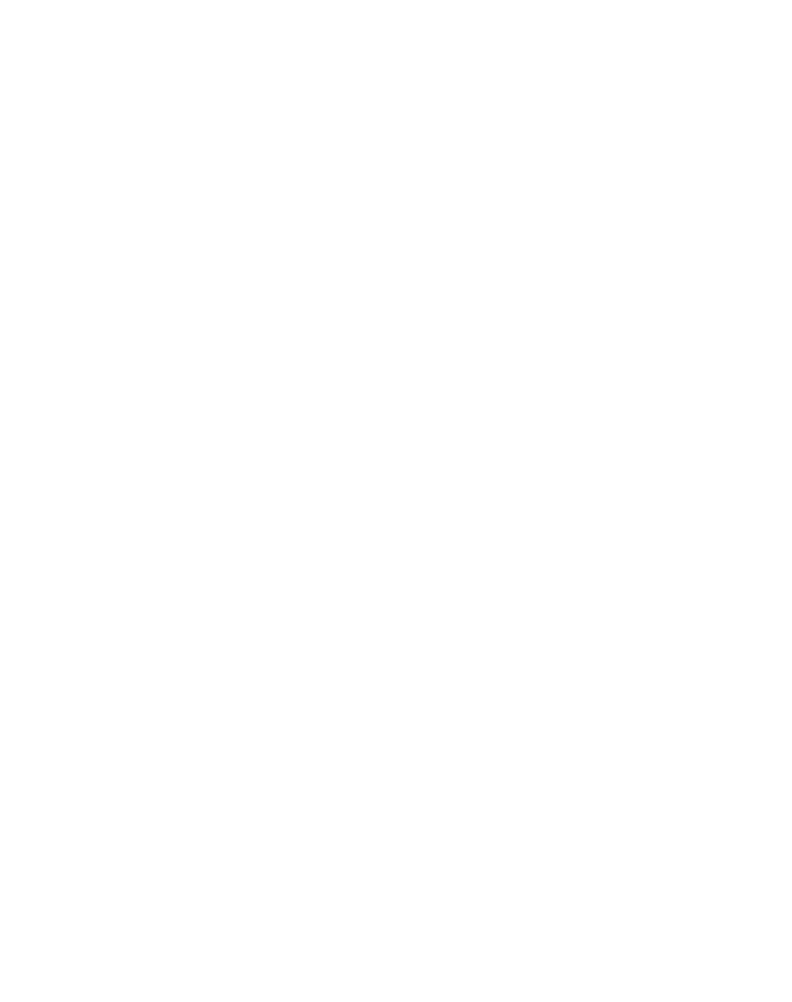

Figure 3. Hypsometric map of natural (up) and anthropogenic (down) relief of the study area

In general, surface exploitation has significantly increased the territory with hypsometric levels up to 240 $\mathrm{m}$ and over $320 \mathrm{~m}$, and reduced the territory 240-320 $\mathrm{m}$. This hypsometry is a consequence of excavating the terrain in the open pits area, which continuously lowered the relief, and depositing the overburden on the formed landfills, which caused the elevation of the terrain with a hilly shape (Figure 3). Similarly, the most obvious changes in the area of the mine "Bełchatów" were recorded at sites of large topographic forms of anthropogenic origin: the deepest point in the excavation is lower by $250 \mathrm{~m}$ than the original height, while the largest increase in height (by 196 $\mathrm{m}$ ) occurred in the area of external landfill (Jaskulski \& Nowak, 2019). In the Macedonian basin Suvodol, over $140 \mathrm{Mm}^{3}$ of coal was excavated, which resulted with a depression $50-100 \mathrm{~m}$ deep and $3 \mathrm{~km}$ in diameter, while a landfill grows nearby as a typical anthropogenic hill (Dragićević \& Milevski 2010).

\section{Slope transformation}

The slope of the terrain is a significant indicator of the morphological structure of the area. The distribution and coverage of slope categories is an indicator of the scope and intensity of morphostructural and exogeomorphological processes, but also of the future influences of these processes on the characteristics and interdependence of denudation and accumulation (Radoš et al., 2012). Therefore, slope models of natu- 
Table 2. Categories and spatial dimensions of slopes

\begin{tabular}{|c|c|c|c|c|}
\hline \multirow{2}{*}{ Inclination $\left(^{\circ}\right)$} & \multicolumn{2}{|c|}{ Natural relief } & \multicolumn{2}{c|}{ Anthropogenic relief } \\
\cline { 2 - 5 } & Area (ha) & Portion (\%) & Area (ha) & Portion (\%) \\
\hline $0-1^{\circ}$ & 136.16 & 15.80 & 125.35 & 14.54 \\
\hline $1-3^{\circ}$ & 163.27 & 18.94 & 167.96 & 19.49 \\
\hline $3-5^{\circ}$ & 117.46 & 13.63 & 106.33 & 12.34 \\
\hline $5-8^{\circ}$ & 159.59 & 18.52 & 106.90 & 12.40 \\
\hline $8-12^{\circ}$ & 159.75 & 18.54 & 103.86 & 12.05 \\
\hline $12-16^{\circ}$ & 73.43 & 8.52 & 70.88 & 8.22 \\
\hline $16-20^{\circ}$ & 34.87 & 4.05 & 54.50 & 6.32 \\
\hline $20-30^{\circ}$ & 16.65 & 1.93 & 87.89 & 10.20 \\
\hline $30-40^{\circ}$ & 0.62 & 0.07 & 30.88 & 3.58 \\
\hline$>40^{\circ}$ & - & - & 7.30 & 0.85 \\
\hline Total & 861.80 & 100.00 & 861.86 & 100.00 \\
\hline
\end{tabular}

Source: Same as table 1

ral and anthropogenic terrain of surface mines have been developed. In the process of terrain slope identification, methods and algorithms integrated into the QGIS program were used, and ten slope classes were singled out (Table 2).

The GIS analysis of natural terrain model showed that slopes up to $5^{\circ}$ were spread over $48.37 \%$ of the territory, which was characterized by weaker leaching and the appearance of smaller gullies, as well as a significant increase in leaching power and erosive processes, resulting in linear erosion. Slopes of $5-12^{\circ}$ are

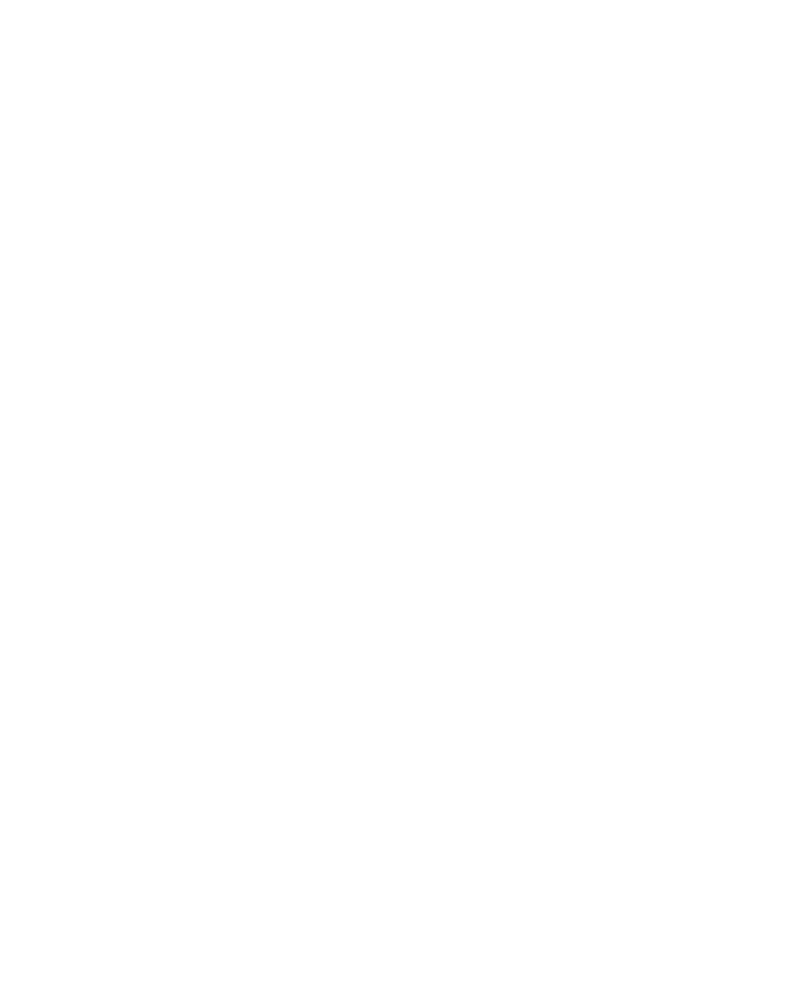

Figure 4. The slope map of natural (up) and anthropogenic (down) relief of the study area spread to $37.06 \%$, while slopes of $12-20^{\circ}$ are spread to $12.57 \%$ of the territory. In general, the morphology of the area was dominated by sloping plains, and quite sloping and slopes morphogenetically shaped by slope processes, while flat surfaces and gentle slopes were significantly represented. On a slope over $20^{\circ}$, there was $2.00 \%$ of the territory affected by intensive slope processes, where as a result strong erosion caused the outbreak of the parent rock substrate to the surface in some places. The area was dominated by medium steep and slightly steep slopes (Table 2, Figure 4).

The GIS analysis of the anthropogenic terrain model showed that slopes up to $5^{\circ}$ are spread on $46.37 \%$ of the territory, slopes $5-12^{\circ}$ on $24.45 \%$, while slopes of $12-20^{\circ}$ on $14.54 \%$ of the area. Morphologically, the area is dominated by sloping plains and flattened surfaces, and almost equally represented mild and quite sloping. On a slope over $20^{\circ}$, there is $14.63 \%$ of the territory affected by intensive slope processes, where medium steep slopes also dominate, with a significant share of steep slopes.

The results of the comparative analysis of the slope model show a significant decrease in the territory of the Đurđevik coal basin with slope up to $16^{\circ}$, except for the category $1-3^{\circ}$, and an increase in the territory over $16^{\circ}$. The decrease of the territory in the category of $5-8^{\circ}(6.12 \%)$ and $8-12^{\circ}(6.49 \%)$ was especially emphasized, and the increase in the category of $20-30^{\circ}$ $(8.27 \%)$ and $30-40^{\circ}(3.51 \%)$. In general, the trend of increasing height differences and the slope of the terrain affected by exploitation is emphasized.

\section{Aspect transformation}

Terrain aspect is a significant indicator of morphological and climatic transformation of the area. Its influence on geomorphological processes is emphasized, because slopes of different aspects differentially ab- 
Table 3. Aspect categories and their spatial coverage

\begin{tabular}{|c|c|c|c|c|}
\hline \multirow{2}{*}{ Aspect } & \multicolumn{2}{|c|}{ Natural relief } & \multicolumn{2}{c|}{ Anthropogenic relief } \\
\cline { 2 - 5 } & Area (ha) & Portion (\%) & Area (ha) & Portion (\%) \\
\hline N $\left(337.5-22.5^{\circ}\right)$ & 262.46 & 30.45 & 188.94 & 21.92 \\
\hline NE $\left(22.5-67.5^{\circ}\right)$ & 130.38 & 15.12 & 114.59 & 13.30 \\
\hline$E\left(67.5-112.5^{\circ}\right)$ & 106.70 & 12.38 & 111.54 & 12.94 \\
\hline SE $\left(112.5-157.5^{\circ}\right)$ & 93.43 & 10.84 & 101.05 & 11.73 \\
\hline S (157.5-202.5 $)$ & 26.20 & 3.04 & 84.57 & 9.81 \\
\hline SW $\left(202.5-247.5^{\circ}\right)$ & 6.79 & 0.79 & 62.60 & 7.26 \\
\hline W $\left(247.5-292.5^{\circ}\right)$ & 56.24 & 6.52 & 79.57 & 9.23 \\
\hline NW $\left(292.5-337.5^{\circ}\right)$ & 179.85 & 20.86 & 118.95 & 13.80 \\
\hline Total & 862.04 & 100.00 & 861.82 & 100.00 \\
\hline
\end{tabular}

Source: Same as table 1.

sorb short-wave radiation, which affects the characteristics of climatic elements as exogenous-geomorphological agents (Radoš et al., 2012). Therefore, a GIS analysis of the spatial orientation of the natural and anthropogenic relief of surface mines was performed. In the aspect identification process, methods and algorithms integrated into the QGIS program were used, where the aspect values were expressed as azimuths $\left(0-360^{\circ}\right)$ and differentiated in eight equal intervals (Table 3 ).

The natural terrain of the Đurđevik area was characterized by the shadiest aspects, while the anthropogenic ones also have the most represented shady aspects,

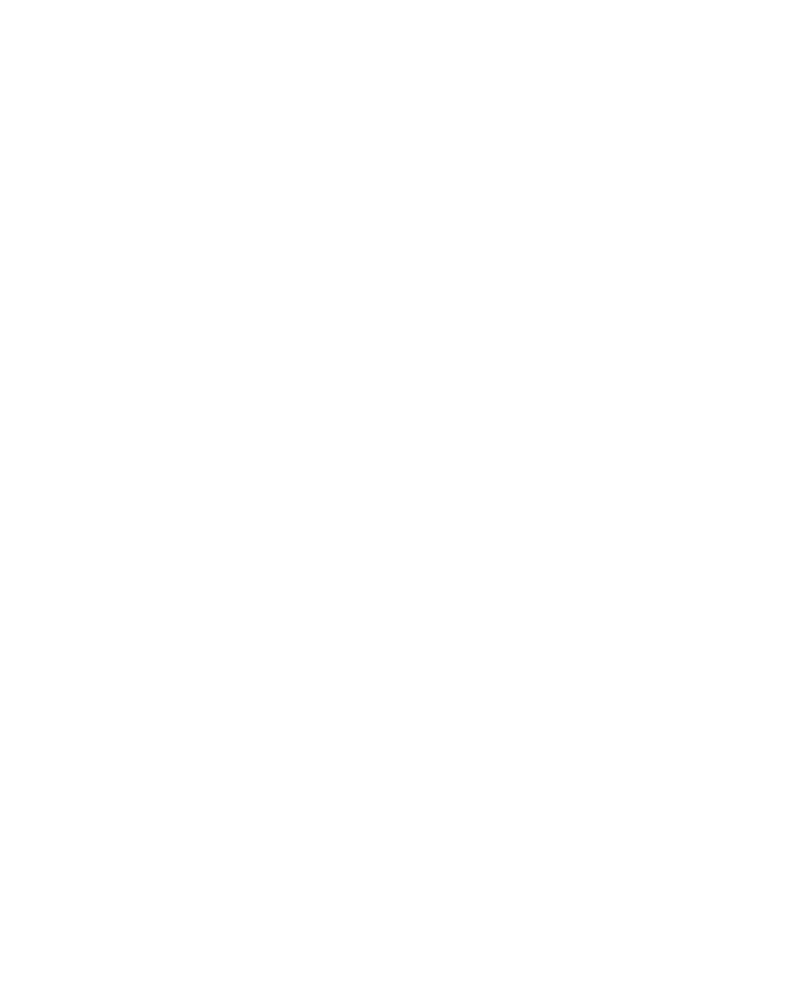

Figure 5. The aspect map of natural (up) and anthropogenic (down) relief of the study area with an emphasized increase in the territory with $\mathrm{E}$, SE, S, SW and W aspects (Table 3; Figure 5). Specifically, with the GIS analysis of the natural terrain model, shady aspects were found and made $66.43 \%$ of the territory, and sunny $14.67 \%$, while eastern aspects (12.38\%) were more represented than western ones (6.52\%). The analysis of the anthropogenic terrain model showed that the shady aspects characterize almost half of the territory (49.02\%), the sunny $28.80 \%$, while the eastern aspects (12.94\%) are significantly more represented than the western ones (9.23\%).

The results of the comparative analysis of aspect models show a decrease in the Đurdevik territory with shady (17.41\%), and an increase with sunny (14.13\%), eastern $(0.56 \%)$ and western aspect $(2.71 \%)$. These transformations are a consequence of the formation of anthropogenic relief of significantly different and more homogeneous aspects in relation to the natural relief. As the biological re-cultivation on the slopes of the completed landfills is conditioned by the slope and aspect, the orientation of the terrain is a significant factor in planning and selecting the type of re-cultivation of the devastated areas of the Đurđevik site. Since in areas with higher insolation, the aspect effect of the slope is more emphasized, landfills should be formed with a larger number of final slopes with northern aspect, and less with southern aspect. However, if due to the amount of overburden and the inclusion of the landfill in the existing terrain it is not possible to avoid sunny aspects, slopes should be provided with a more moderate slope to mitigate insolation consequences (Knežiček et al., 2006; Smajić et al., 2018).

\section{Hydrographical transformation}

The hydrographic backbone of the Đurđevik coal basin is the river Oskova, a left tributary of the Spreča, with its tributaries. Oskova and its tributary Gostelja frame the basin on the north and east sides, respectively, from the main collecting arteries of surface 
water (Figure 6). According to morphometric measurements, $25.45 \mathrm{~km}$ of watercourses touched the exploitation field in Oskova, and $24.71 \mathrm{~km}$ in Gostelja.

The results of the GIS analysis of four sheets of a topographic map, scale 1:25,000, show that the watershed between Oskova and Gostelja used to run through the central part of the area earlier, in a south-north direction. All watercourses of the researched area flowed in this direction, which before exploitation, north of the exploitation field, flowed into Oskova, while today they are significantly disorganized. In particular, the river network of the area affected by the exploitation was consisted of several watercourses, the sources which are located south and southwest along the perimeter of the exploitation field. Their length in the area of mines, according to the natural relief, was $34.08 \mathrm{~km}$, and the density of the river network was 3.95 $\mathrm{km} / \mathrm{km}^{2}$.The length of watercourses with constant water yield was $16.94 \mathrm{~km}$ or $1.97 \mathrm{~km} / \mathrm{km}^{2}$, and occasional $17.14 \mathrm{~km}$ or $1.99 \mathrm{~km} / \mathrm{km}^{2}$. The area between Kažalj stream and Gostelja was predominantly characterized by a centrifugal type of river network. The total length of watercourses within the exploitation field was 50.17 $\mathrm{km}$, while $67.93 \%$ of their length was destroyed by surface exploitation. In the northwestern area, the 765.67 $\mathrm{m}$ long Oskova stream has been relocated (Figure 6). Similar but more intense river transformations affected the Kolubara basin, when the river of the same name was diverted to the tributary Peštan, which resulted in increased coastal erosion, lateral migration of the river flow, loss of land, etc. (Dragićević et al. 2017; Dragićević et al. 2012).

Surface exploitation in the Đurđevik coal basin resulted in 40.09 ha of anthropogenic lakes (Figure 6). The largest is Lake Odorovići, whose area is 10.82 ha, and the length of the shore is about $3.20 \mathrm{~km}$. The lake was formed in 1979 due to the partitioning of the valley of the Kažalj stream with the overburden of a landfill of the same name. It is located at an altitude of $320.00 \mathrm{~m}$, between the hamlets of Kupjerusi in the east, Odorovici in the west, and the re-cultivated landfill "Kažalj" in the north, while on the south side several mountain streams flow into the lake. The depth of the lake is $22.50 \mathrm{~m}$, while the length of the water mirror in the north-south direction is $797.11 \mathrm{~m}$, and the width in the east-west direction is $308.64 \mathrm{~m}$. The emphasized annual oscillation of the lake level is mainly conditioned by the pluviometric regime and evaporation, and it is especially pronounced during the summer period when the water level drops for 1.5 $\mathrm{m}$, while the oscillations of levels in drier years are possible up to $3 \mathrm{~m}$.

The second largest is Lake Bašigovci (8.22 ha), formed in 1985 in the pit of the surface mine "Bašigovci", which has been completely transformed

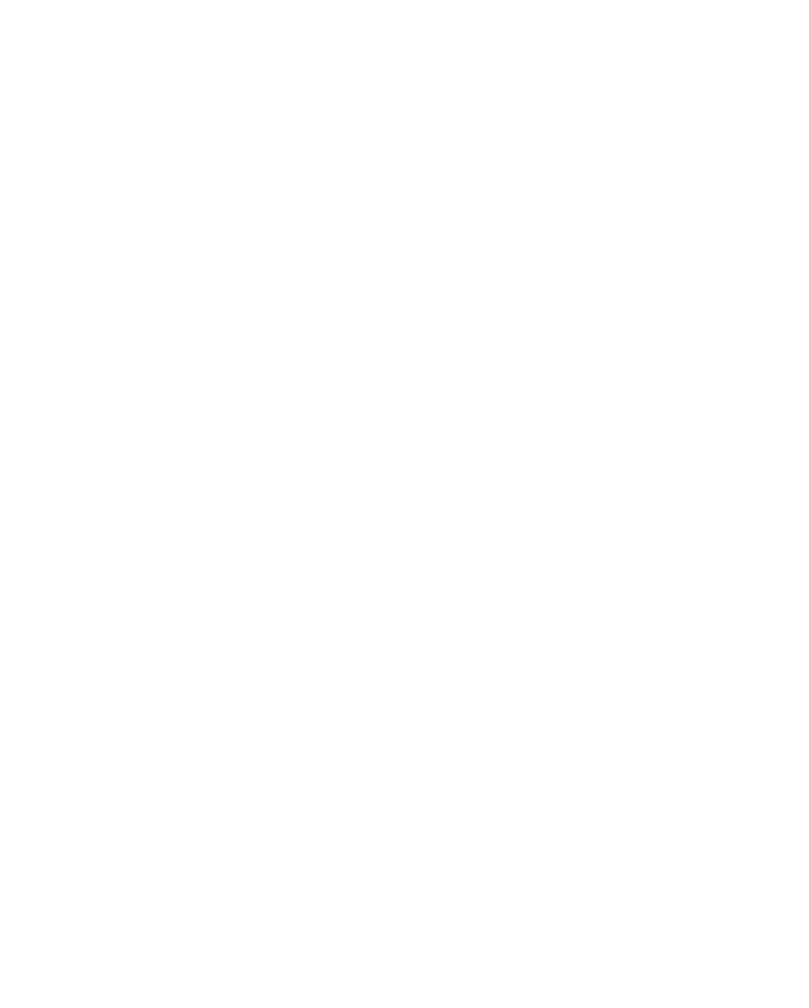

Figure 6. Digital Elevation Model of natural (up) and anthropogenic (down) relief of the study area

into a sports and recreational complex by the regulation plan. For example, the positive practice of using anthropogenic reservoirs for tourism purposes, which should be pursued, is visible in the German lignite basin Lower Lusatian where 9.75 thousand ha are currently under water (Deshaies, 2020), in the Šaleška valley in Slovenia 200 ha (Šterbenk, 2006) etc. The length of the shore of Bašigovačko Lake is $1.37 \mathrm{~km}$, the length in the north-south direction is $393.32 \mathrm{~m}$, while the width in the east-west direction is $333.38 \mathrm{~m}$. This lake is located at an altitude of $250.50 \mathrm{~m}$, while the maximum depth of the lake is $45.50 \mathrm{~m}$. The lake is dominantly filled with groundwater and less with surface water from the immediate catchment area, it has an overflow system in the northeast, so the annual oscillations of water levels are not significantly pronounced.

The third largest in this basin is Lake Suhodanj with an area of 7.90 ha. The lake was formed in 1988 in the landfill area of the former open pit mine Suhodanj, and due to the partitioning of the Brnjica stream valley by the Stupnica landfill. The level of the lake is at a height of $293.00 \mathrm{~m}$, while its depth is $15 \mathrm{~m}$. The length of the shore of this lake is $1.43 \mathrm{~km}$, the length in the east-west direction is $404.97 \mathrm{~m}$, while the width in the north-south direction is $351.07 \mathrm{~m}$. The Stupnica landfill is quite porous, and the lake water sinks significantly through the marly limestones embankment and flows into the Gostelja river. The annual oscilla- 
tion of the lake level is significant, in the summer period the water level is lower than the spring by about 1 $\mathrm{m}$, while the oscillations of the levels in drier years are possible by 2-3 $\mathrm{m}$.

Lake Cenda is much smaller with an area of 3.20 ha; it is located at an altitude of $269.20 \mathrm{~m}$, between the hamlets of Cenda in the south, Jahić in the east and Beširević in the northeast, and the landfill of the former open mine "Višća I" in the west. The lake was formed in 1982, and its depth is $26.70 \mathrm{~m}$. The length of the shore of this lake is $1.10 \mathrm{~km}$, the length in the north-south direction is $299.31 \mathrm{~m}$, while the width in the east-west direction is $196.36 \mathrm{~m}$.

In the western part of the area there is Lake Brestovica with an area of 3.28 ha. The lake was formed in the period 1974-1982 due to the partitioning of the
Brestovica stream valley by the landfill "Kažalj". The length of the shore of this lake is $797.12 \mathrm{~m}$, the length in the east-west direction is $273.51 \mathrm{~m}$, the width in the north-south direction is $195.95 \mathrm{~m}$, while the depth of the lake is $4 \mathrm{~m}$. The annual oscillation of the lake level is conditioned by the pluviometric regime mainly, by the evaporation and sinking of the lake water through the landfill, and this is especially pronounced in summer when the water level drops by $0.60 \mathrm{~m}$ on average, although larger oscillations are also possible. In the area of Odžak and Šahići there are also several smaller anthropogenic lakes with an area of up to one hectare. Some of these lakes in the Đurdevik coal basin have existed for many years, have a natural tributary and an overflow system, and have formed their own water regime.

\section{Conclusion}

Based on the comparative analysis of DEM natural and anthropogenic terrain, the paper identifies and geovisualizes the landscape transformation of the surface mine area in the Đurđevik coal basin. The results of the research show that 861.78 ha of natural surface were devastated in the past 74 years, and that complex concave and convex anthropogenic relief forms were formed, which significantly transform the Đurđevik landscape. Comparative analysis of DEMs determined the trend of increasing height differences and the slope of the terrain affected by exploitation. The uniformity of the average height of both terrains was emphasized, while the increase in the height difference of the anthropogenic terrain was higher by $156.48 \mathrm{~m}$ than the natural one. The territory with hypsometric levels up to $240 \mathrm{~m}$ and over $320 \mathrm{~m}$ was increased, and 240-320 m was reduced.

The territory of the basin with slope up to $16^{\circ}$ has been significantly reduced, except in the category $1-3^{\circ}$, while territory with slope over $16^{\circ}$ increased. The territory with slope category $5-8^{\circ}$ and $8-12^{\circ}$ has been especially reduced, while territory with slope $20-30^{\circ}$ and $30-40^{\circ}$ increased. The homogeneity of the exposition structure of the anthropogenic relief was emphasized, the territory with shady aspect was reduced, and it was increased with sunny, eastern and western aspect.

Surface mines also disrupted the orographic watershed between Oskova and Gostelja, while the river network, whose density was $3.95 \mathrm{~km} / \mathrm{km}^{2}$, was completely disorganized. This completely disrupted the natural potamological function of the watercourse of this area; $16.94 \mathrm{~km}$ of permanent and $17.14 \mathrm{~km}$ of occasional watercourses were completely destroyed, $765.67 \mathrm{~m}$ of the Oskova river were relocated, 40.09 ha of anthropogenic reservoirs were formed, etc.

In general, the most obvious landscape transformations occurred at locations of large topographic forms of anthropogenic origin. The largest height difference was found in the active open pits "Potočari" (230 m) and "Višća II" (106 m), and in the landfills "Stupnica" $(100 \mathrm{~m})$, "Višća" $(80 \mathrm{~m})$ etc.

As the Đurđevik mine is legally obliged to recultivate the devastated terrain due to coal exploitation, identified and geovisualized indicators of landscape transformation of surface mine areas can be of great importance when planning and performing land recultivation of devastated areas, but also the final design of the post-exploitation landscape.

\section{Acknowledgements}

The paper was created within the framework of the research project "Recent physical-geographic changes in Đurdevik basin caused by surface exploitation of coal", which was approved and funded under Program 4, Internal Call of the University of Tuzla for financing/co-financing of projects in the field of science of importance for the Federation BeH in 2019, entitled "Support for research of importance for the Federation in 2019." (No. 01-6211-1-IV/19) from 26.11.2019. 


\section{References}

Arsenović, S., Urošević, M., Sretenović, B., Cvetkov, V., \& Životić, D. (2016). Modelling of a coal seam of the deposit Đurdevik (BiH) by means of $2 \mathrm{D}$ reflection seismic imaging. Journal of Geophysics and Engineering, 13(3), 422-428. https://doi. org/10.1088/1742-2132/13/3/422

Boengiu, S., Ionuş, O., \& Marinescu, E. (2016). Manmade changes of the relief due to the mining activities within Husnicioara open pit (Mehedinți County, Romania). Procedia Environmental Sciences, 32, 256 263. https://doi.org/10.1016/j.proenv.2016.03.030

Brejcha, M., Staňková, H., \& Černota, P. (2016). Landscape modelling of past, present and future state of areas affected by mining. Perspectives in Science, 7, 151-155. https://doi.org/10.1016/j.pisc.2015.11.024

Deshaies, M. (2020). Metamorphosis of Mining Landscapes in the Lower Lusatian Lignite Basin (Germany): New uses and new image of a mining region. Les Cahiers de la recherche architecturale urbaine et paysagère, 7. https://doi.org/10.4000/craup.4018

Dinić, J. (2007). Čovek i reljef [People and relief]. Belgrade: Serbian Geographical Society. (in Serbian)

Dragićević, S., Pripužić, M., Živković, N., Novković, I., Kostadinov, S., Langović, M., Milojković, B., \& Čvorović, Z. (2017). Spatial and Temporal Variability of Bank Erosion during the Period 1930-2016: Case Study-Kolubara River Basin (Serbia). Water, 9(10), 748. https://doi.org/10.3390/w9100748

Dragićević S., Živković N., Roksandić M., Kostadinov S., Novković I., Tošić R., Stepić M., Dragićević, M., \& Blagojević, B. (2012). Land Use Changes and Environmental Problems Caused by Bank Erosion: A Case Study of the Kolubara River Basin in Serbia. In Appiah-Opoku S. (Ed.). Environmental Land Use Planning, (pp. 3-20). https://dx.doi. org/10.5772/50580

Dragićević, S., \& Milevski, I. (2010). Human Impact on the Landscape - examples from Serbia and Macedonia. In Zlatic M. (Ed.) Global Change - Challenges for soil management. Germany: Catena Verlag Gmbh, 298-309.

Drešković, N., \& Mirić, R. (2017). Regionalna geografija Bosne i Hercegovine I [Regional Geography of Bosnia and Herzegovina I]. Sarajevo: Faculty of Science, University of Sarajevo. (in Bosnian)

Dulias, R. (2016). Anthropogenic Landforms in the Upper Silesian Coal Basin. In: The Impact of Mining on the Landscape. Environmental Science and Engineering. (pp. 51-82). Cham: Springer. https://doi. org/10.1007/978-3-319-29541-1 3

Florinsky, I.V., Skrypitsyna, T.N., \& Luschikova, O.S. (2018). Comparative accuracy of the AW3D30
DSM, ASTER GDEM, and SRTM1 DEM: A case study on the Zaoksky testing ground, Central European Russia, Remote Sensing Letters, 9(7), 706-714. https://doi.org/10.1080/2150704X.2018.1468098

Gupta, M., Mohanty, K.K., Kumar, D., \& Banerjee, R. (2014). Monitoring surface elevation changes in Jharia coalfield, India using synthetic aperture radar interferometry. Environmental Earth Sciences, 71, 2875-2883. https://doi.org/10.1007/s12665-0132664-9

Harnischmacher, S., \& Zepp., H. (2014). Mining and its impact on the earth surface in the Ruhr District (Germany). Zeitschrift für Geomorphologie, Suppl. 58(3), 3-22. https://doi.org/10.1127/0372$\underline{8854 / 2013 / \mathrm{S}-00131}$

Harnischmacher, S. (2007). Anthropogenic impacts in the Ruhr District (Germany): A contribution to anthropogeomorphology in a former mining region. Geografia Fisica e Dinamica Quaternaria, 30(2), 185-192.

Jaskulski, M., \& Nowak, T. (2019). Transformations of Landscape Topography of the Bełchatów Coal Mine (Central Poland) and the Surrounding Area Based on DEM Analysis. ISPRS International Journal of Geo-Information, 8(9), 403. https://doi.org/10.3390/ ijgi8090403

Knežiček, Ž., Uljić, H., \& Husagić, R. (2006). Oblikovanje i prenamjena prostora površinskih kopova lignite [Shaping and changing areas of lignite open pits]. Tuzla: Mining Institute. (in Bosnian)

Lepirica, A. (2013). Geomorfologija Bosne i Hercegovine [Geomorphology of Bosnia and Herzegovina]. Sarajevo: Sarajevo Publishing. (in Bosnian)

Machowski, R., Rzetala, M.A., Rzetala, M., \& Solarski, M. (2016). Geomorphological and Hydrological Effects of Subsidence and Land use Change in Industrial and Urban Areas. Land Degradation \& Development, 27(7), 1740-1752. https://doi.org/10.1002/ $\underline{\text { ddr. } 2475}$

Pandey, A.C., \& Kumar, A. (2014). Analysing topographical changes in open cast coal-mining region of Patratu, Jharkhand using CARTOSAT-I Stereopair satellite images. Geocarto International, 29(7), 731-744. https:// doi.org/10.1080/10106049.2013.838309

Radoš, D., Lozić, S., \& Šiljeg, A. (2012). Morphometrical Characteristics of the Broader Area of Duvanjsko Polje, Bosnia and Hercegovina. Geoadria, 17(2). 177-207.

Salihović, S., Musić, O., \& Operta, M. (2008): Ispitivanje jalovinskih materijala na području Tuzlanskog kantona u svrhu korištenja za tehničku i biološku rekultivaciju na primjeru PK Višća i 
Šikulje [Testing of tailings materials in the Tuzla Canton for the purpose of use for technical and biological reclamation on the example of the open pits Višća and Šikulje]. Proceedings of the 2nd Congress of Geographers of Bosnia and Herzegovina (pp. 461-470). Neum: Geographical Society in the Federation of B\&H. (in Bosnian with English abstract)

Smajić, S., Kulenović, S., \& Pavić, D. (2009). Geographical Consequences of the Surface Exploitation of Coal on the Area of Tuzla Basin. Geographica Pannonica, 13(2), 32-40.

Smajić, S., Hadžimustafić, E., \& Kadušić, A. (2018). Identification and geovisualization of morphological-hydrographic changes in the area of the open pit “Turija”. Revija za geografijo, 13(2), 39-58.

Smajić, S. (2012). Geografske promjene na prostoru Tuzlanskog bazena uzrokovane površinskom eksploatacijom uglja [Geographical changes in the Tuzla Basin area caused by surface coal mining] (Doctoral dissertation). University of Tuzla, Faculty of Science, Tuzla. (in Bosnian)

Smajić, S., \& Hadžimustafić, E. (2016). Recentne morfološko-hidrografske promjene na području površinskih kopova sjevernog krekanskog sinklinorijuma [Recent morphological-hydrographic changes in the area of surface mines of the northern Kreka's synclinorium]. Proceedings of the Faculty of Science, Volume Geography, 12, 5-22. (in Bosnian with English abstract)

Smajić, S., \& Hadžimustafić, E. (2017). Morfološkohidrografske promjene u južnom dijelu banovićkog basena uzrokovane površinskom eksploatacijom uglja [Morphological-hydrographic changes in the southern part of the Banovići basin caused by surface coal mining]. Proceedings of the 4th Congress of Geographers of Bosnia and Herzegovina (pp. 554567). Sarajevo: Geographical Society in the Federation of B\&H. (in Bosnian with English abstract)

Takaku, J., Tadono, T., Tsutsui, K., \& Ichikawa, M. (2018). Quality Improvements of 'AW3D' Global DSM Derived from ALOS PRISM. Proceedings IGARSS 2018 - 2018 IEEE International Geoscience and Remote Sensing Symposium (pp. 1612-1615), 22-27 July 2018, Valencia, Spain. doi: 10.1109/IGARSS.2018.8518360
Thomas, J., Prasannakumar, V., \& Vineetha, P. (2015). Suitability of spaceborne digital elevation models of differentscales in topographic analysis: an example from Kerala, India. Environmental Earth Sciences, 73, 1245-1263. https://doi.org/10.1007/ $\underline{\text { s12665-014-3478-0 }}$

Šterbenk, E. (2006). Uspješan program oporavka okoliša za područja pogođena negativnim utjecajem rudarstva, energetike i industrije, temelj za razvoj turizma (primjer Šaleške doline - Slovenija) [Successful environmental recovery program for areas affected by the negative impact of mining, energy and industry, the basis for tourism development: example of the Šaleška valley - Slovenia]. Proceedings - International scientific seminar "Tourism as a factor of regional development" (pp. 253-260). Tuzla: University of Tuzla. (in Bosnian with English abstract)

Wu, Z., Lei, S., Lu, Q., \& Bian, Z. (2019). Impacts of Large-Scale Open-Pit Coal Base on the Landscape Ecological Health of Semi-Arid Grasslands. Remote Sensing, 11(15), 1820. https://doi.org/10.3390/ $\underline{\mathrm{rs} 11151820}$

\section{$\infty$}

ALOS AW3D30 DSM (2018). Japan Aerospace Exploration Agency (JAXA). Tokyo.

Data base (2020). Federal Geodetic Administration (FGA). Sarajevo.

Long-term work program of BCM "Đurđevik", 20172032. (2018). Đurđevik: BCM.

Map Satellite (2018). Google Earth Proo.

Situational plans "Potočari" and "Višća II" (2020). Scale 1:2,500. Đurđevik: BCM.

The Map of Soil (1969). Scale 1:50,000. Sarajevo: The Institute for Agriculture and Soil.

The map of actual forest vegetation of Bosnia and Herzegovina (1980). Scale 1:500,000. Sarajevo: The Faculty of Forestry.

Topographic map (1956). Scale 1:50,000. Belgrade: Military Geographical Institute.

Topographic map (1966). Scale 1:25,000, section Šerići-1381, Živinice-1382, Banovići-1446, Đurđevik-1447. Belgrade: Military Geographical Institute. 